\title{
Influence of storage time of pulp and paper industry wastewaters in AOX determination
}

\author{
Micaela A. R. Soares ${ }^{1, *}$, Manuela Marques ${ }^{1}$, and Maria Teresa Rodrigues ${ }^{1}$ \\ ${ }^{1}$ RAIZ - Instituto de Investigação da Floresta e Papel, Rua José Estevão, 3800-783 Aveiro, Portugal
}

\begin{abstract}
The feasibility of storing wastewater samples from pulp and paper industry during more than 5 days (time recommend by ISO 56673:2018) for AOX determination was addresses in this study. Samples were collected before and after the aerobic biological treatment of a Portuguese industry. Experimental protocol included AOX measurements at days 4, 5, $6,8,11,13,15,18$ and 20 after sampling. Results obtained indicate that storage time is not matrix-dependent and it can be extended up to 20 days, which clearly improves management of laboratory activities concerning AOX determination.
\end{abstract}

\section{Introduction}

Adsorbable organically bound halogens (AOX) constitute a group of organic compounds containing chlorine, bromine and iodine that are adsorbable by activated carbon. These substances may pose a potential threat to the environment due to their propensity to bioaccumulate, carcinogenicity or chronic toxicity [1-3].

Anthropogenic activities are the main source of AOX in the environment as a result of several industrial process. For example, in water treatment industry, halogen-based oxidants used for disinfection can react with naturally occurring organic matter, thus leading to the formation of organohalogen by-products [4]. In pulp and paper production (P\&P), AOX formation is a side-effect of pulp bleaching as chlorine based oxidizing agents react with residual lignin from wood fibers [5].

Analytical measure of AOX consists in the determination of organically bound chlorine, bromine and iodine (expressed as chloride) adsorbable on activated carbon. ISO 9562:2004 is an international standard that describes the analytic method for AOX quantification in liquid matrices, which comprises i) adsorption of organic compounds onto activated carbon, ii) organic halides displacement, iii) combustion of activated carbon in oxygen stream and iv) hydrogen halides absorption in an acceptor solution followed by microcoulometry [6]. Sample handling, preservation and storage are critical points in AOX determination to retard chemical and biological reactions, which unavoidably evolved after sampling from source [7]. In fact, sample preservation for AOX determinations depend upon three aspects: i) $\mathrm{pH}$ adjustment, ii) microbial inhibition and iii) suppress residual oxidant activity.

Sample $\mathrm{pH}$ can affect hydrolysis reaction rate of AOX compounds depending on the functional groups present, number and type of halogens. If hydrolysis reactions occur

\footnotetext{
* Corresponding author: micaela.soares@thenavigatorcompany.com
} 
organic halides can be loss and thus AOX levels be underestimated, thus acidification until $\mathrm{pH}<2$ is recommended [6]. Microbial activity may enhance degradation of organohalogen compounds, therefore the imposition of $\mathrm{pH}$ level that inhibit bacterial growth are usually endorsed [6]. Residual oxidant presence in samples may enhanced formation of AOX during holding time between sampling and analysis; thus quenching agent like $\mathrm{NaSO}_{3}$ are usually added to neutralize oxidant activity after sample collection [6].

Despite the importance of sample storage, to the authors' best knowledge the influence of time storage of liquid matrices is scarcely addressed in literature. Preservation and handling of water samples as established in ISO 5667-3:2018 [8] indicates 5 days as a best practice (not validated) for AOX sample storage, however this standard is not referred by [6]. Additionally [6] gives no information in what concerns sample storage time, whenever analysis is not possible right after sampling.

This work aims to examine the viability of storing wastewater samples from pulp and paper industry for more than 5 days (recommend by [8] for AOX determination. In addition, this study also focused on establishing a model that includes storage time to assess impact on the overall management of laboratory activities concerning AOX determination.

\section{Materials and methods}

\subsection{Sampling and storage}

The samples used were collected at two points of a wastewater treatment process of a Portuguese P\&P manufacturer: before (EETS) and after (ESTS) the aerobic biological treatment. After sampling 5 liters at each point (day 0), samples were immediately checked for the presence of oxidizing agents as described in [6], preserved to $\mathrm{pH}<2$ with nitric acid, and thus transported to laboratory in cooling conditions. Then, each sample was divided in ten portions, assuring homogeneity conditions, and analysed in triplicate (day 0 ). Subsequent triplicate measurements were carried out at days 4, 5, 6, 8, 11, 13, 15, 18 and 20 after sampling. Until analysis day, samples were maintained between 0 to $4^{\circ} \mathrm{C}$ in high density polyethylene containers.

\subsection{AOX determination}

AOX determinations were performed following the shaking procedure described in [6]. Briefly, samples were shaken for 1 hour in the presence of sodium nitrate and active charcoal; after adsorption, suspension was filtered and the mineral halides were shifted by rinsing the filter and the charcoal with a diluted acidified sodium nitrate solution; filter and charcoal residue were then incinerated in a AOX analyser (multi $\mathrm{X} \circledast 2$ 2500 - Analytik Jena $\mathrm{AG}$ ) at $1050^{\circ} \mathrm{C}$ in the presence of a $\mathrm{O}_{2}$ gas flow; hydrogen halides produced were measured by microcoulometry. Quality control scheme for each day of analysis included the parameters listed in Table 1. Previous validation studies lead to the method characteristics presented in Table 2. In addition the statement on the validity of the method, detailing its fitness for the intended use is also presented in the referred table.

\subsection{Calculations}

The preservation time was considered to have been exceeded, according to the following condition:

$$
\frac{\Delta}{\Delta_{\max }}>1.0
$$


Where:

$\Delta$ is the difference between $\mathrm{Xi}$ (mean of the triplicate analysis in each day after sampling) and $\mathrm{X}_{0}$ (triplicate analysis in sampling day).

$\Delta_{\max }$ is the maximum allowed difference between $\mathrm{Xi}$ and $\mathrm{X}_{0}$ and it represents the measurement uncertainty associated to $\mathrm{X}_{0}$.

Table 1. Quality control scheme established for routine analysis of AOX in wastewaters.

\begin{tabular}{|c|c|c|c|c|}
\hline & Description & $\begin{array}{c}\mathrm{N}^{\circ} \\
\text { replicates }\end{array}$ & Frequency & Acceptance criteria \\
\hline $\begin{array}{l}\text { Titration } \\
\text { cell }\end{array}$ & Verification of factor a [6] & 2 & $\begin{array}{l}\text { Each day } \\
\text { of analysis }\end{array}$ & $0.97-1.03$ \\
\hline $\begin{array}{c}\text { Blank } \\
\text { sample }\end{array}$ & $\begin{array}{c}\text { Same procedure as sample, but } \\
\text { with } 100 \mathrm{ml} \text { of diluted } \mathrm{HNO}_{3} \\
\text { instead of sample }\end{array}$ & 2 & $\begin{array}{c}\text { Each day } \\
\text { of analysis }\end{array}$ & $\begin{array}{c}\mid \text { Replicate } 1 \text {-Replicate } 2 \mid \leq 1.2 \\
\mu \mathrm{g} / 1\end{array}$ \\
\hline $\begin{array}{c}\text { Sample } \\
\text { Replicates }\end{array}$ & & 3 & $\begin{array}{c}\text { Each } \\
\text { sample } \\
\text { analysed }\end{array}$ & Relative range $\leq 6.5 \%$ \\
\hline $\begin{array}{c}\text { Daily } \\
\text { Check } \\
\text { standards }\end{array}$ & $\begin{array}{l}\text { Three standards: } \\
\text { 1) } 25 \mu \mathrm{g} / 1 \text { (LOQ); 2) } 100 \mu \mathrm{g} / \mathrm{l} ; 3) \\
250 \mu \mathrm{g} / 1 \\
\text { Standards prepared with } 4 \text { - } \\
\text { chlorophenol or 2-chlorobenzoic } \\
\text { acid }\end{array}$ & 2 & $\begin{array}{c}\text { Each day } \\
\text { of analysis }\end{array}$ & $\begin{array}{l}\text { Acceptance criteria: } 10 \% \text { from } \\
\text { nominal value } \\
\text { Relative range: } \\
\text { 1) } \leq 9.0 \% ; 2 \text { ) } \leq 7.0 \% ; 3 \text { ) ) } \\
\leq 1.8 \% \text {. }\end{array}$ \\
\hline
\end{tabular}

\subsection{Management of laboratory activities according to sample storage time for AOX determination}

For evaluating the sample storage time in the laboratory capacity for processing AOX determination, the following variables were established:

$\mathrm{N}_{\mathrm{eq}}$ Number of equipments available for AOX analysis (without autosampler)

tprep Time for sample and standard preparation, in hours

tads Time for sample and standards adsorption by activated charcoal, in hours

Nrep Number of replicas for blanks, standards and samples analysis

tana Time for replica analysis in AOX equipment, in hours

tQC Time for daily quality control check, in hours

tava Daily time available for analysis

$\mathrm{n}_{\mathrm{i}} \quad$ Time between sampling and analysis, in days

tpreserv Maximum preservation time, in days

On a daily basis, the lab processing capacity for AOx determination is given by:

$$
N_{\text {sample }}=\frac{N_{e q} \times\left[t_{a v a}-\left(t_{Q C}+t_{a n a} \times N_{r e p}+t_{a d s}+t_{p r e p}\right)\right]}{t_{a n a} \times N_{r e p}}
$$

Additionally, a number of samples able to be processed within the admissible storage time, $\mathrm{N}_{\mathrm{adm}}$ is given by:

$$
N_{\text {adm }}=N_{\text {sample }}\left(t_{\text {preserv }}-n_{i}\right)
$$


For comparison of the gain associated to the increases of tpreserv, the following parameter was evaluated:

$$
\text { Analytic process gain }=\frac{t_{\text {preserv } \_1}-n_{i}}{t_{\text {preserv } \_2}-n_{i}}
$$

Table 2. Statement on the validity of the AOX method according to [6], detailing its fitness for the intended use

\begin{tabular}{|c|c|c|}
\hline $\begin{array}{l}\text { Validation } \\
\text { parameter }\end{array}$ & \multirow[b]{2}{*}{ 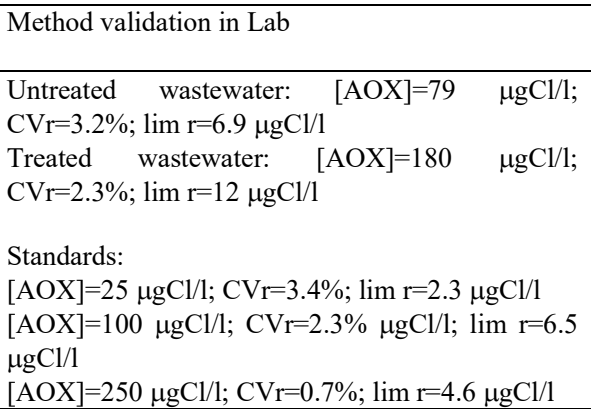 } & \multirow{2}{*}{ 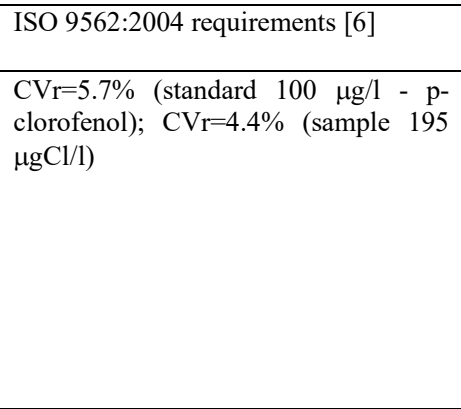 } \\
\hline Repeatability & & \\
\hline Reproductibility & $\mathrm{CVR}=8.97 \%$ & $\begin{array}{l}\text { CVR }=13.0 \%(\text { standard } 100 \mu \mathrm{g} / \mathrm{l}) \\
\mathrm{CVR}=9.82 \%(\text { sample } 195 \mu \mathrm{gCl} / \mathrm{l})\end{array}$ \\
\hline $\begin{array}{l}\text { Participations in } \\
\text { interlaboratory } \\
\text { comparisons }\end{array}$ & $\begin{array}{l}17 \text { participations; average } 9 \text { participants; } \\
\text { measuring range: } 2.63 \text { to } 9.06 \mathrm{mgCl} / 1 ;-0.87<\mathrm{Z} \text { - } \\
\text { score }<1.61 \text {. Drms. rel }(\mathrm{EIL})=4.95 \%\end{array}$ & Not mentioned \\
\hline $\begin{array}{l}\text { Measurement } \\
\text { uncertainty }{ }^{1}\end{array}$ & $15 \%$ & $\begin{array}{l}\text { Not mentioned, but results must be } \\
\text { presented with two significant figures. }\end{array}$ \\
\hline Recovery & $\begin{array}{l}\text { Recovery range : } 92 \text { to } 110 \%(\mathrm{n}=8) \\
\text { Average Recovery: } 101.8 \% \mathrm{sd}=6.2 \%\end{array}$ & Not mentioned \\
\hline $\begin{array}{l}\text { Completeness } \\
\text { of the total } \\
\text { adsorption }^{2}\end{array}$ & $\begin{array}{l}\text { Untreated wastewater: relative range }=0.7-4.6 \% \\
(\mathrm{SD}=1.6 \%), \mathrm{n}=8 \\
\text { Treated wastewater: relative range }=0.1 \text { a } 4.9 \% \\
(\mathrm{SD}=2 \%), \mathrm{n}=5\end{array}$ & $\begin{array}{c}{[\mathrm{AOX}]<100 \mu \mathrm{g} / \mathrm{l}: \text { absolute range } \leq 10} \\
\mu \mathrm{g} / 1 \\
{[\mathrm{AOX}] \geq 100 \mu \mathrm{g} / \mathrm{l}: \text { relative range } \leq 10 \%}\end{array}$ \\
\hline $\begin{array}{l}\text { Initial check } \\
\text { standards }^{3}\end{array}$ & $\begin{array}{l}\text { Correlation coefficient: } 0.9993 \text { a } 1.0000(\mathrm{n}=6) \\
\text { Slope: } 1.003 \text { a } 1.028(\mathrm{n}=6)\end{array}$ & $\begin{array}{l}\text { Recover function: } \\
\text { Correlation coefficient } \geq 0.999 \\
\text { Slope: } 0.95 \text { to } 1.05\end{array}$ \\
\hline $\begin{array}{l}\text { Statement on } \\
\text { the validity of } \\
\text { the method }\end{array}$ & $\begin{array}{l}\text { From the results obtained, the Laboratory com } \\
\text { characteristics of the Test Standard, namely: } \\
\text { 1) CVr lower than the one indicated in [6] } \\
\text { 2) CVR of the laboratory lower than CVR present in } \\
\text { 3) Equipment stability over time was ensured by: } \\
\text { 3.1) measured value vs nominal value of the sta } \\
\text { coefficient } \geq 0.999 \text {, slope within the requirements of } \\
\text { 3.2) Daily verification of titration cell within limit } \\
\text { 3.3) daily check of the control standard (100 } \mu \text { g } \\
\text { of } 0.8 \% \text { that is below the limit of the } 10 \% \text { [6]) } \\
\text { 3.4) compliance with the criteria for complete adsc } \\
\text { 4) The measurement uncertainty allows to present t } \\
\text { required by [6] }\end{array}$ & $\begin{array}{l}\text { ies with the statistical performance } \\
\text { 6] } \\
\text { ards in the working range (correlation } \\
\text { ]) } \\
\text { 0.97 to 1.03) [6] } \\
\text { 1) within the criteria (target deviation } \\
\text { tion with active carbon. } \\
\text { results with two significant figures, as }\end{array}$ \\
\hline $\begin{array}{r}\text { Comple } \\
\text { the sam } \\
\text { Analysi } \\
\text { value ar } \\
\text { SD - standard devia } \\
\mathrm{R} \text { - reproducibility } \\
\mathrm{R} \text { - Repeatability } \\
\text { Lim r - repeatability }\end{array}$ & $\begin{array}{l}\text { urement uncertainty, does not include sampling, is expres } \\
\text { the combined relative standard uncertainty multiplied b } \\
n \text {, corresponds to a confidence level of approximately } 95^{\circ} \\
\text { ness of the total adsorption was verified by using } 2 \text { differ } \\
\text { active charcoal quantity; } \\
\text { of blank sample and at least five samples within workin }\end{array}$ & $\begin{array}{l}\text { as the expanded relative uncertainty, which is } \\
\text { coverage factor } \mathrm{k}=2 \text {, which, for a normal } \\
\text { alculation method used accordingly to [9]. } \\
\text { est sample volumes and/or dilution steps with } \\
\text { nge with further comparison of the measured }\end{array}$ \\
\hline
\end{tabular}




\section{Results and discussion}

\subsection{Effect of storage time in AOX determination}

Figure 1 depicts the effect of storage time in AOX determination for P\&P wastewaters.
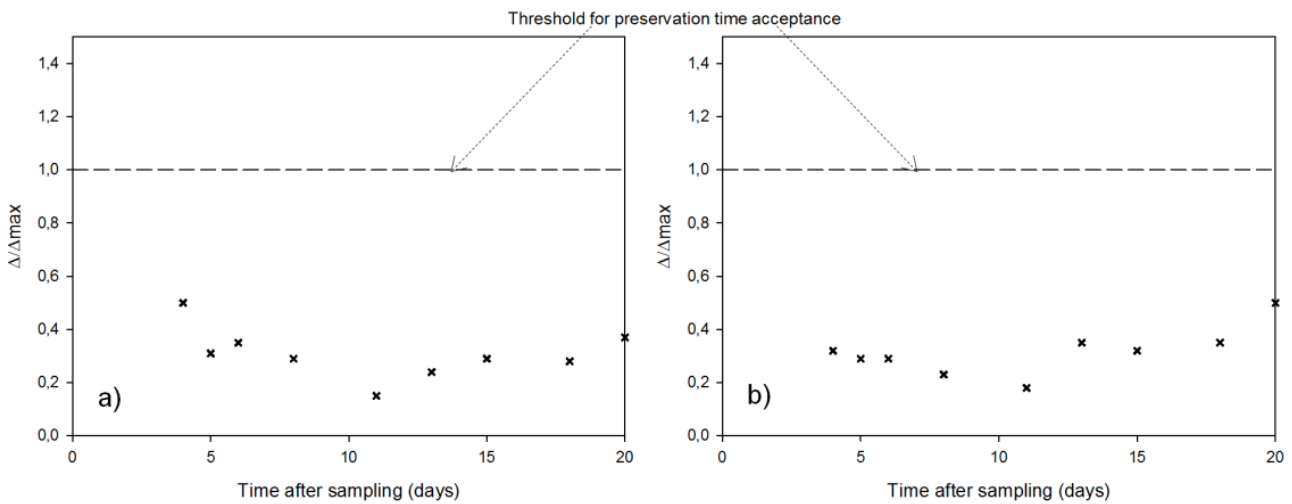

Fig. 1. Effect of storage time in preservation of P\&P wastewaters: a) EETS b) ESTS.

Results obtained clearly show that for P\&P wastewaters before and after biological treatment is possible to extend sample preservation between 0 to $4^{\circ} \mathrm{C}$ up to 20 days after sampling, without compromising the test specimen integrity for AOX quantification. Despite storage time is considered a critical aspect to retard chemical and biological reactions, the preservation conditions imposed in this study to the samples after sampling $(\mathrm{pH}<2$ and inhibition of active chlorine) proved to be adequate.

It must be highlighted that AOX is a lumped parameter [10] and the results obtained in this study indicate that no relevant loss of organic halides occur or that formation of AOX is prevented by neutralization of the residual oxidant present. In addition, storage time was not matrix-dependent. Nevertheless, this behaviour can be dependent on the halogen type, since according to [11] adsorbable organic chlorine is more stable than adsorbable organic bromine or iodine. Thus maximum storage time cannot be extrapolated to other wastewater proveniences since individual circumstances of the sample matrix like functional groups present, number and type of halogens presents may condition sample storage requirements, and should be individually investigated.

\subsection{Effect of storage time in managing samples analysis for AOX determination}

The compliance of storage time for AOX determination may be demanding to a laboratory and it depending on factors like i) number of available equipment, ii) time of measurement, iii) requirements of method quality control, iv) number of incoming samples amongst others.

In this study, the scenario described in Table 3 was considered for evaluating the gain obtained in the analytic process due to the increase in the maximum allowed sample preservation time for AOX determination. 
Table 3. Variable definition for the scenario evaluated.

\begin{tabular}{|l|l|l|}
\hline Variable & Definition & Value \\
\hline $\mathrm{N}_{\mathrm{eq}}$ & $\begin{array}{l}\text { Number of equipments available for AOX analysis (without auto- } \\
\text { sampler) }\end{array}$ & 1 \\
\hline tprep & Time for sample and standard preparation, in hours & 1 \\
\hline tads $_{\mathrm{Nrep}}$ & Time for sample and standards adsorption by activated charcoal, in hours & 1 \\
\hline tana & Number of replicas for blanks, standards and samples analysis & 2 \\
\hline toc & Time for replica analysis in AOX equipment, in hours & 0.25 \\
\hline tava & Time for daily quality control check, in hours & 1.5 \\
\hline tpreserv & Daily time available for analysis & 8 \\
\hline $\mathrm{N}_{\text {sample }}$ & Maximum preservation time, in days & 5 or 20 \\
\hline
\end{tabular}

Figure 2 presents the gain associated to the increase of tpreserv from 5 to 20 days.

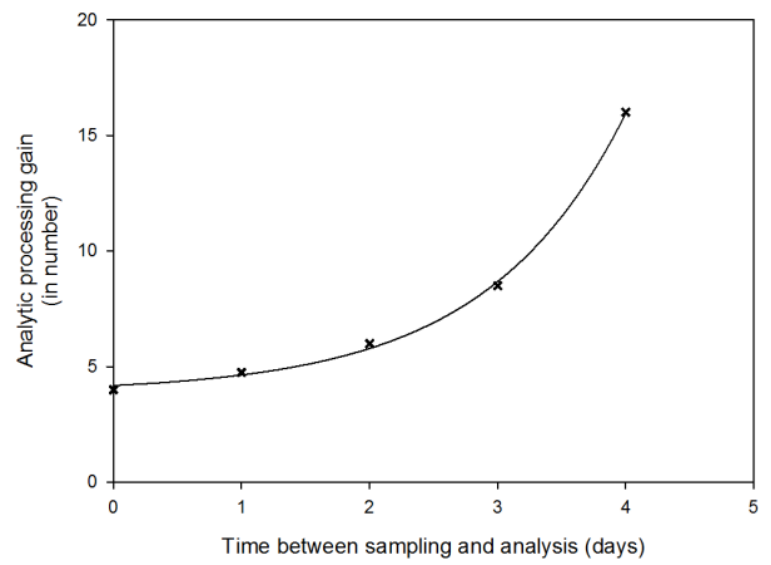

Fig. 2. Analytic process gain due when sample storage time is extended from 5 to 20 days.

The gain for the scenario where the sample is analysed in the sampling day (day 0 ) is 4 , meaning that the lab could receive 160 and 40 samples when the time preservation is 20 and 5 days respectively, and this represents a good gain. Nevertheless, when there is a delay between sampling and analysis, which is the typical scenario, the gain increases exponentially reaching the value 16 when that delay is 4 days. In this situation, the lab could only process 8 samples with a 5 days preservation time while the extension to a 20 days period for storage allowed processing 128 samples more. This gain is an outcome once it allows the lab to fulfil the ISO 9562 requirements avoiding thereby method deviations.

\section{Conclusions}

Sample time storage for AOX determination in wastewater from P\&P industry is of critical importance to assure that chemical and biological reactions are hindered after sampling. On the other hand, sample storage is an issue with relevant impact in managing laboratory activities associated to AOX determination.

The results obtained in this study show that extension of the preservation time up to 20 days is feasible for samples collected before and after biological wastewater treatment in a P\&P 
industry. In addition, this finding clearly improves management of laboratory activities concerning AOX determination, once it avoids method deviations by a factor of 16 .

\section{References}

[1] M Zhang, A Buekens, X Li, J. Hazard. Mater. 304 (2016).

[2] A Kinani, S Kinani, S Bouchonnet, TrAC - Trends Anal. Chem. 85 (2016)

[3] Y Xie, L Chen, R Liu, J Tian, Bioresour. Technol. 265 (2018).

[4] A Kinani, H Salhi, S Bouchonnet, S Kinani J. Chromatogr. A 1539 (2018).

[5] F Torrades, E Cecilia, Analyst 126 (2001).

[6] International Organization for Standardization, ISO 9562:2004-Water qualityDetermination of adsorbable organically bound halogens (AOX) (2004).

[7] A Kinani, S Kinani, B Richard, M Lorthioy, S Bouchonnet TrAC - Trends Anal. Chem. 85 (2016).

[8] International Organization for Standardization, ISO 5667-3:2018 - Water quality -Sampling -- Part 3: Preservation and handling of water samples (2018).

[9] International Organization for Standardization, ISO 11352:2012- Water quality -Estimation of measurement uncertainty based on validation and quality control data (2012).

[10] S Cherif, Fradj R Ben, A Jrad, Accredit. Qual. Assur. 11 (2006).

[11] G Hua, D A Reckhow, J. Am. Water Works Assoc. 104 (2012) 